\author{
홀스타인 젓소의 주요 경제형질에 대한 보증종모우와 후보종모우의 능력 비교 \\ 최유림*·조광현*·전병순*・백광수*·박병호*·임현주*·김효선*·조주현**·안병석*·김내수*** \\ 농촌진흥청 국립축산과학원*, 농협중앙회 젖소개량사업소**, 충북대학교***
}

\title{
Comparison of Proven and Young Holstein Bulls for Major Economic Traits
}

\author{
You Lim Choi*, Kwang Hyun Cho*, Byeong Soon Jeon*, Kwang Soo Baek*, Byoungho Park*, Hyun Joo Lim*, \\ Hyo Sun Kim*, Joo Hyun Cho**, Byeong Seog Ahn* and Nae Soo Kim*** \\ National Institute of Animal Science, RDA*, Dairy Cattle Improvement Center, NACF**, \\ Chungbuk National University***
}

\begin{abstract}
The Objective of this study was to compare performances of proven and young holstein bulls bred in Korea. Proven bulls are categorized into the imported and the korean ones. Data from 148,329 heads of daughters of 1,128 bulls from 1990 to 2004 were used in this study. Proven bulls showed higher milk yield than young bulls in same year. Young bulls, however, always yielded more milk than korean bulls when proven bulls were categorized into the imported and the korean ones. Hence, it was proven that dairy bull selection program had properly been functioned in Korea. Selected bulls, which were korean proven bulls and young bulls, yielded higher milk fat than imported bulls as the selection was weighted on the yield of the milk fat. This comparison was based on the performances of daughters without the consideration of the semen price. Semen price of the imported proven bulls were higher than the korean proven bulls and the semen of young bulls was free. Hence, the performances of korean bulls with the consideration of the preferential effect would be much higher than others, and further studies are necessary.
\end{abstract}

(Key words : Holstein, Proven bull, Young bull, Progeny test)

\section{I. 서 론}

젖소 선발 프로그램을 운영하는 가장 큰 목적은 유전적 개량을 최대로 하여 그에 따른 최고의 수익을 얻기 위함 이다 (Abdallah와 McDaniel, 2000). 유전적 개량을 최대로 하기 위해서는 우수한 종모우의 선발여부가 가장 큰 영향 을 미친다(Powell과 Norman, 1989). 젖소의 우유 생산능력 과 같이 암컷에서만 발현되는 한성형질을 개량하기 위하 여 종모우를 이용하는 방법은 선조의 혈통정보 (pedigree information)에 근거하여 선발된 후보종모우를 이용하거나 후대검정 (progeny testing)을 실시하여 자손의 능력에 근거 하여 선발된 보증종모우를 이용하는 방법이 있다(Freeman, 1975; Abdallah와 McDaniel, 2002). 즉 후보종모우와 보증 종모우는 별개의 집단이 아니라 세대를 달리하고 있는 집 단이다. 일반적으로 정 (positive)의 유전적 개량 추세를 갖 는 집단에서는 나이가 어린 가축들의 평균 유전능력은 나 이가 많은 가축들의 평균능력보다 우수하므로, 상대적으 로 나이가 어린 후보종모우들을 적당한 비율로 이용하는
것이 보증종모우를 사용할 때 보다 더 빠른 유전적 개량 을 이룰 수도 있다 (Nizamani와 Berger, 1996). 이는 보증종 모우를 생산하기 위해서는 일정한 규모의 후보종모우들이 후대검정을 위한 자손을 생산하여야 하며 후보종모우와 보증종모우간에도 최소한 한세대의 격차가 있으므로 후보 종모우의 비율이 높아지면 세대간격이 그만큼 줄어들기 때문에 개량에 긍정적 반응을 기대할 수 있는 것이다.

후보종모우의 이용이 개량에 효과를 가지기 위해서는 이들의 평균능력이 앞세대에 선발된 보증종모우들의 능력 과 유사하여야 하므로 동일 시점에서 세대가 다른 보증종 모우들과 후보종모우들의 능력을 동일시점에서 비교하는 것은 후보종모우의 이용비율을 얼마나 할 것인지 결정할 수 있기 때문에 필요한 일이다. 이러한 필요성 때문에 보 증종모우와 후보종모우의 능력을 비교한 연구결과들이 많 이 보고되었다. Loyd와 Hargrove (1988), McCraw 등 (1980), Vinson과 Freeman (1972)은 보증종모우의 능력이 후보종모 우보다 높게 나타났다고 보고하였고, McDaniel과 Bell (1992), Abdallah과 McDaniel (2000)은 후보종모우를 사용했

Corresponding author: You Lim Choi, Animal Genetic Improvement Division, National Institute of Animal Science, Eoryong-ri Seonghwan-eup, Cheonan-Si, Chungcheongnam-Do, Korea 300-801

Tel: 041-580-3388, Fax: 041-580-3419, E-mail: cyl3383@rda.go.kr 
을 때의 유량과 유지량의 개량추세는 보증종모우를 사용 했을 때와 비슷하다고 보고하였다. 그러나 Meinert 등 (1992)은 후보종모우의 능력이 보증종모우 보다 높다고 하 는 등 보증종모우와 후보종모우의 능력간 차이를 개량집 단에 따라 다르게 보고하고 있다. Abdallah와 McDaniel (2002)은 보증종모우가 생산능력은 후보종모우 보다 높지 만 정액가격 등을 고려할 경우 후보종모우를 사용하는 것 이 경제적 이득을 취할 수 있다고 보고하였다.

우리나라에서는 1987년부터 젖소 후대검정사업을 실시 하고 있으나 사업에 대한 낙농가의 낮은 호응으로 보증종 모우 선발을 위한 후보종모우 딸소 확보에 많은 어려움을 겪고 있다. 낙농가들이 후대검정사업 참여를 꺼리는 이유 는 White (1975)와 $\mathrm{McCraw}$ 등 (1980)이 보고한 바와 같이 후보종모우의 능력에 대한 낙농가들의 신뢰가 보증종모우 에 비해 떨어지기 때문에 기인한 것으로 생각된다.

그러므로 본 연구는 국내에서 사용된 보증종모우(한국 형 보증종모우와 수입 보증종모우 포함)와 후보종모우의
딸소의 능력을 비교하여 한국형 보증종모우 생산을 위한 후대검정사업의 활성화의 핵심요소인 후보종모우 선발의 적정성 판단하고, 낙농가들에게 후보종모우를 일정부분 사용을 권장하는 자료를 만들어 후보종모우 사용에 대한 부정적 선입견을 완화시킴으로서 효율적인 후대검정사업 추진의 기틀을 마련하고자 실시하였다.

\section{․ 재료 및 방법}

\section{1. 분석자료}

분석자료는 2008년 상반기 농촌진흥청 국립축산과학원 에서 유전능력이 평가된 종모우 1,311두 중 1990년부터 2004년 사이에 사용된 종모우 1,128두를 보증종모우(한국 형 보증종모우와 수입 보증종모우 포함)와 후보종모우로 구분하였으며 이들의 딸소 148,329 두의 1 산차 305 일 산유 능력검정기록을 활용하였다 (Table 1).

Table 1. Number of bulls and records of daughter by year

\begin{tabular}{|c|c|c|c|c|c|c|}
\hline \multirow{2}{*}{ Use of year } & \multicolumn{3}{|c|}{ Bulls } & \multicolumn{3}{|c|}{ Records of daughter } \\
\hline & Young Bull & Korean Bull & Imported Bull & Young Bull & Korean Bull & Imported Bull \\
\hline 1990 & 8 & - & 55 & 100 & - & 1,036 \\
\hline 1991 & 10 & - & 81 & 206 & - & 2,547 \\
\hline 1992 & 6 & - & 59 & 125 & - & 1,282 \\
\hline 1993 & 18 & - & 97 & 249 & - & 4,920 \\
\hline 1994 & 13 & - & 62 & 134 & - & 6,761 \\
\hline 1995 & 11 & 8 & 75 & 222 & 1,240 & 6,109 \\
\hline 1996 & 13 & 2 & 70 & 230 & 655 & 7,341 \\
\hline 1997 & 13 & 1 & 52 & 247 & 337 & 12,293 \\
\hline 1998 & 13 & 2 & 54 & 608 & 365 & 14,222 \\
\hline 1999 & 14 & 2 & 50 & 350 & 711 & 12,024 \\
\hline 2000 & 9 & 2 & 53 & 264 & 236 & 17,484 \\
\hline 2001 & 12 & 2 & 52 & 240 & 574 & 17,596 \\
\hline 2002 & 14 & 1 & 63 & 363 & 272 & 18,456 \\
\hline 2003 & 15 & - & 61 & 510 & - & 13,103 \\
\hline 2004 & 3 & 1 & 72 & 97 & 65 & 4,533 \\
\hline 2005 & - & 3 & - & - & $91^{2)}$ & - \\
\hline 2006 & - & 2 & - & - & $52^{2)}$ & - \\
\hline 2007 & - & 2 & - & - & $50^{2)}$ & - \\
\hline 2008 & - & 1 & - & - & $29^{2)}$ & - \\
\hline sub-total & 172 & $29^{1)}$ & 956 & 3,945 & 4,677 & 139,707 \\
\hline total & & 1,128 & & & 148,329 & \\
\hline
\end{tabular}

1) Twenty nine Korean proven bulls were excluded as these were selected from 172 Young bulls for progeny test. (e.g. One Korean proven bull of year 2008 was 1 of 15 Young bulls from the progeny test in 2003).

2) The record of the daughters of Korean proven bulls from 2005 to 2008 was the record of the daughters of Young bulls selected by the progeny test untill 2004. 


\section{2. 통계분석}

본 자료를 분석하기 위하여 사용된 종모우의 종류, 사 용년도 및 종모우의 종류와 사용년도간의 교호작용을 요 인으로 한 분산분석을 실시하였으며, 분산분석에서 유의 성이 인정된 경우 평균간 다중 검정을 실시하였다. 분석 프로그램으로 SAS 9.1을 사용하였다.

\section{III. 결과 및 고찰}

본 연구에서 조사된 유량 및 유성분에 대한 분산분석 결과는 Table 2에 있다. Table 2에 표시한 각 요인에 대한 유의성 검정 결과를 보면 유량에 대한 종모우 종류, 종모 우 사용년도 및 종모우 종류와 사용년도간의 교호작용 모 두 고도의 유의성 $(\mathrm{p}<0.01)$ 을 나타내었다. 유지방, 유단백 질 및 무지고형분 등의 유성분에 있어서 사용년도와 교호 작용은 고도의 유의적 효과 $(\mathrm{P}<0.01)$ 를 나타내고 있는 것 으로 나타났으나 종모우의 종류는 유지방과 무지고형분에 는 유의적 영향이 없는 것으로 나타났다.

우리나라에서 후보종모우 정액이 처음 사용되기 시작한 1990년부터 2004년까지 각각의 년도에 사용된 종모우 종 류에 따른 딸소들의 생산능력을 보증종모우(한국형 보증 종모우와 수입 보증종모우 포함)와 후보종모우로 구분하 여 비교한 결과는 Table 3에 제시되어 있다.

유량은 비교된 모든 년도에서 보증종모우 딸소들의 생 산능력이 후보종모우 딸소들의 생산능력에 비해 유의적으 로 $(\mathrm{p}<0.01)$ 높게 나타나고 있다. 이러한 결과는 보증종모 우 중 다수를 차지하는 수입 보증종모우의 능력이 높았기 때문이 기도하지만 보증종모우 정액은 유상으로 구입하 여야 하고 후보종모우 정액은 무상으로 사용함에 따라 Atagi 등 (1999)과 Weigel (1996)이 보고한 바와 같이 보증 종모우 정액을 능력이 높은 암소에 선별적으로 사용하였 을 가능성과 보증종모우에서 태어난 자손이 특별한 관리 를 받았을 가능성도 포함하고 있는 것으로 보인다. 한편 최근 년도에 가까워질수록 유량의 차이는 점차 줄어드는 경향을 보이고 있는 것으로 나타나고 있는데 이는 선발되 는 후보종모우의 능력이 높아짐에 따라 나타나는 결과이 거나 또는 수입 자유화에 따라 다양한 능력대의 외국 보
증종모우 정액이 자유롭게 수입됨에 따라 나타나는 현상 인 것으로 보인다. 유지방 및 유단백질은 년도에 따른 능 력차이가 일정한 경향을 가지고 있지 않은 것으로 나타나 고 있는 반면 무지고형분은 1995년 이후부터 보증종모우 의 능력이 후보종모우에 비해 높게 나타나고 있는데 이러 한 현상은 후보종모우 선발시 유지방을 제외한 다른 유성 분이 선발형질에 고려되지 않았기 때문에 나타난 결과로 사료된다.

Fig 1부터 Fig. 4까지는 유량, 유지방, 유단백질 및 무지 고형분에 대하여 사용된 종모우의 종류를 수입 보증종모 우, 한국형 보증종모우 및 후보종모우로 구분하고 이들 3 가지 종류의 종모우의 생산능력을 동일한 년도별로 비교 하여 나타내고 있다. 2003년도에는 한국형 보증종모우가 선발되지 않아 자료로 제시하지 못하였으며 2004년도의 생산능력이 다른 연도에 비해 떨어진 것은 2004년도에 사 용된 종모우 딸소의 기록이 다른 년도에 비해 아직 많이 나타나지 않았기 때문에 나타난 결과로 보인다.

Fig. 1에는 유량에 대한 종모우간의 능력을 비교한 결과 가 나타나 있는데 모든 종모우에서 년도가 경과함에 따라 정 (positive)의 변화추세를 보이고 있고 특히 후보종모우

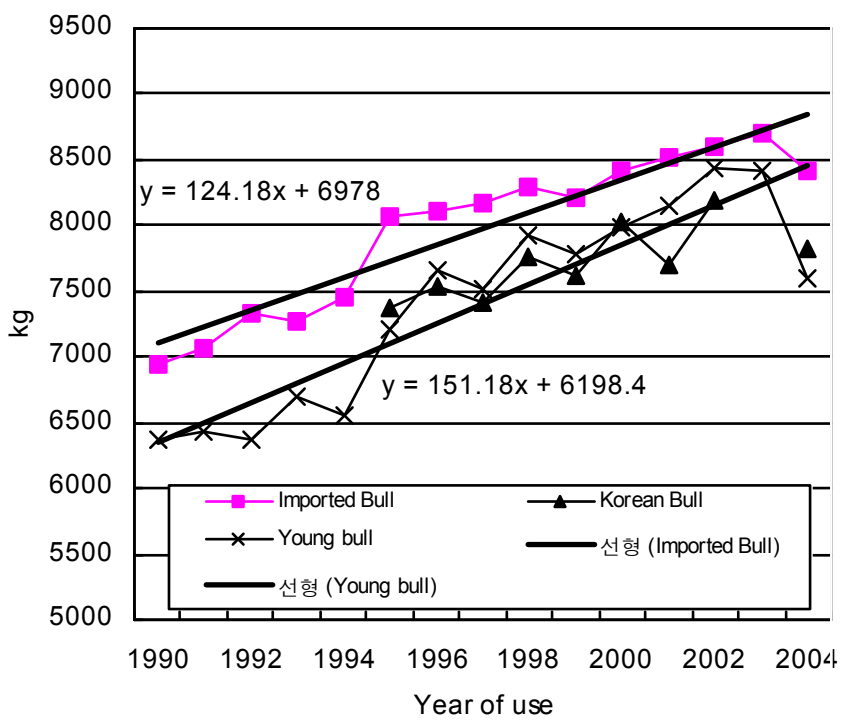

Fig 1. Least square means of milk yield by year.

Table 2. Analysis of variance for milk yield and composition traits

\begin{tabular}{|c|c|c|c|c|c|c|c|c|}
\hline \multirow{2}{*}{ Source } & \multicolumn{2}{|c|}{ Milk yield } & \multicolumn{2}{|c|}{ Fat $\%$} & \multicolumn{2}{|c|}{ Protein $\%$} & \multicolumn{2}{|c|}{ SNF \% } \\
\hline & $\mathrm{df}$ & MS & $\mathrm{df}$ & MS & df & MS & $\mathrm{df}$ & MS \\
\hline Bull & 1 & $979402978 * *$ & 1 & 0.000146 & 1 & $0.73046^{* *}$ & 1 & 0.04380 \\
\hline Year of use & 14 & $356643078^{* *}$ & 14 & $5.06602 * *$ & 14 & $2.43485^{* *}$ & 14 & $2.15107 * *$ \\
\hline Year*Bull & 14 & $12672355^{* *}$ & 14 & $0.77784 * *$ & 14 & $9.50341 * *$ & 14 & $1.50413 * *$ \\
\hline Error ${ }^{1)}$ & 148299 & 2410687.3 & 147255 & 0.24518 & 147964 & 0.04435 & 147791 & 0.11336 \\
\hline
\end{tabular}

** $\mathrm{p}<0.01$

1) Missing values of traits : Fat - 1044, Protein - 335, SNF - 508. 
Table 3. Least square means of milk yield and composition traits from daughters of the proven and young bulls by year

\begin{tabular}{|c|c|c|c|c|c|c|c|c|}
\hline \multirow{2}{*}{$\begin{array}{c}\text { Year of } \\
\text { use }\end{array}$} & \multicolumn{2}{|c|}{ Milk yield } & \multicolumn{2}{|c|}{ Fat $\%$} & \multicolumn{2}{|c|}{ Protein $\%$} & \multicolumn{2}{|c|}{$\mathrm{SNF} \%$} \\
\hline & Proven Bull ${ }^{1)}$ & Young Bull & Proven Bull & Young Bull & Proven Bull & Young Bull & Proven Bull & Young Bull \\
\hline 1990 & $7151.5^{* *}$ & 6375.4 & $3.68 * *$ & 3.51 & $3.19 * *$ & 3.33 & $8.67 * *$ & 8.87 \\
\hline 1991 & $7157.9 * *$ & 6431.0 & 3.69 & 3.68 & $3.20 * *$ & 3.26 & 8.70 & 8.72 \\
\hline 1992 & $7336.9 * *$ & 6366.9 & 3.61 & 3.64 & 3.21 & 3.25 & $8.65^{*}$ & 8.71 \\
\hline 1993 & $7309.8^{* *}$ & 6697.1 & $3.69 *$ & 3.75 & $3.19 * *$ & 3.25 & $8.67 * *$ & 8.83 \\
\hline 1994 & $7452.8^{* *}$ & 6563.7 & 3.78 & 3.71 & 3.19 & 3.21 & 8.68 & 8.70 \\
\hline 1995 & $8014.4^{* *}$ & 7215.5 & 3.79 & 3.77 & $3.16^{*}$ & 3.13 & $8.71 * *$ & 8.64 \\
\hline 1996 & $8110.8^{* *}$ & 7660.1 & 3.84 & 3.83 & $3.22 * *$ & 3.13 & $8.80 * *$ & 8.64 \\
\hline 1997 & $8143.7 * *$ & 7508.4 & 3.86 & 3.86 & 3.19 & 3.20 & $8.85 * *$ & 8.76 \\
\hline 1998 & $8297.7 * *$ & 7929.4 & 3.81 & 3.82 & $3.14 * *$ & 3.21 & 8.82 & 8.82 \\
\hline 1999 & $8209.6^{* *}$ & 7784.0 & 3.83 & 3.78 & $3.13^{*}$ & 3.17 & 8.81 & 8.79 \\
\hline 2000 & $8419.6^{* *}$ & 7979.5 & 3.82 & 3.87 & $3.12 * *$ & 3.16 & 8.78 & 8.76 \\
\hline 2001 & $8510.3^{* *}$ & 8150.3 & 3.91 & 3.86 & $3.13^{* *}$ & 3.08 & $8.79 * *$ & 8.73 \\
\hline 2002 & $8601.3^{* *}$ & 8429.9 & $3.79 * *$ & 3.88 & $3.11^{*}$ & 3.08 & 8.76 & 8.75 \\
\hline 2003 & $8703.4 * *$ & 8422.2 & 3.83 & 3.82 & $3.11^{*}$ & 3.09 & $8.77 * *$ & 8.72 \\
\hline 2004 & $8415.8^{* *}$ & 7604.2 & $3.85^{* *}$ & 4.00 & 3.11 & 3.09 & 8.77 & 8.73 \\
\hline $\mathrm{SE}^{2)}$ & 4.2 & 25.6 & 0.001 & 0.008 & 0.001 & 0.003 & 0.001 & 0.005 \\
\hline
\end{tabular}

$* * \mathrm{p}<0.01, * \mathrm{p}<0.05$.

1) Proven bull includes Imported and Korean bulls.

2) Pooled Standard Error.

의 증가 추세는 년간 $151.2 \mathrm{~kg}$ 으로 수입 보증종모우의 증 가 추세 $124.2 \mathrm{~kg}$ 에 비해 더 급격하게 증가하는 것으로 나 타나고 있다. 동일한 년도에 사용된 한국형 보증종모우와 후보종모우의 유량을 비교한 결과 모든 년도에서 후보종 모우의 능력이 한국형 보증종모우의 능력보다 높게 나타 나고 있어 나이가 어린 종모우의 평균 생산능력이 나이가 많은 종모우들의 평균 생산능력보다 뛰어나다는 보고 (Nizamani와 Berger, 1996)와 일치하는 결과이다.

Fig. 2에는 유지방에 대한 종모우간의 능력을 비교한 결 과가 나타나 있는데 유량의 변화추세와 같이 모든 종모우 에서 년도가 경과함에 따라 정 (positive)의 변화추세를 보 이고 있다. 유지방에 대해 한국형 보증종모우가 수입 보 증종모우와 후보종모우에 비해 높은 생산 능력을 보이고 있는 것은 한국형 보증종모우 선발지수식에 고려되는 형 질 중 유지방에 대한 가중치가 가장 높기(국립축산과학원, 2008) 때문에 나타난 결과로 사료된다.

Fig. 3는 유단백질에 대한 종모우간의 능력을 비교한 결 과를 보여주고 있는데 종모우간의 뚜렷한 능력 차이를 보 이지는 않으나 수입 종모우가 년도에 따른 능력의 변이가 가장 적은 특징을 보여주고 있는데 이것은 우리나라에 수

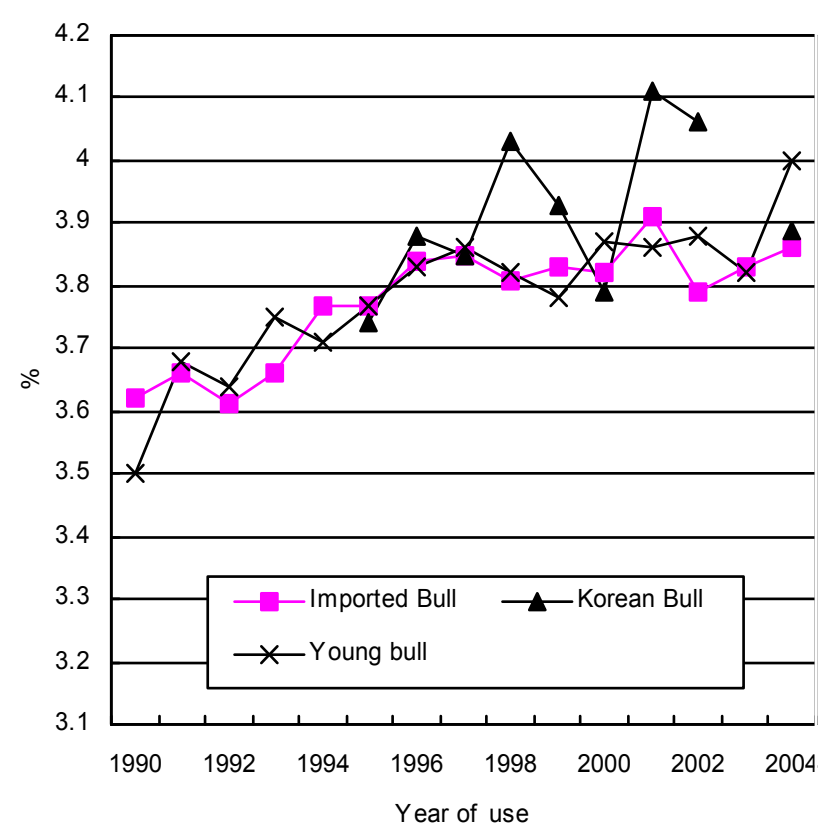

Fig. 2. Least square means of Fat $\%$ by year. 


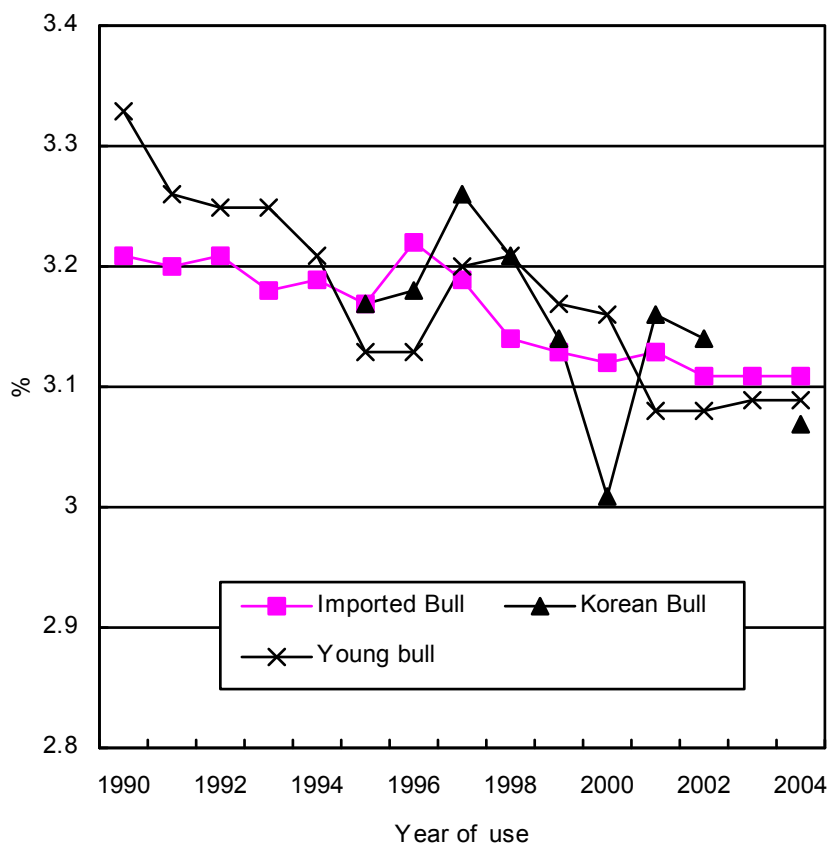

Fig. 3. Least square means of protein $\%$ by year.

입하는 종모우의 대부분을 차지하는 북미지역의 종모우는 유단백질에 대한 집중적인 선발이 이루어져 유단백질에 대하여 일정한 능력을 기본적으로 갖고 있기 때문에 나타 난 결과로 사료된다.

Fig. 4는 무지고형분에 대한 결과인데 종모우간 능력의 우위를 판단할 수 있는 뚜렷한 경향치를 보이고 있지는 않다.

유량의 경우 보증종모우의 생산능력이 후보종모우에 비 해 높게 나타나고 있으며 보증종모우를 수입 보증종모우

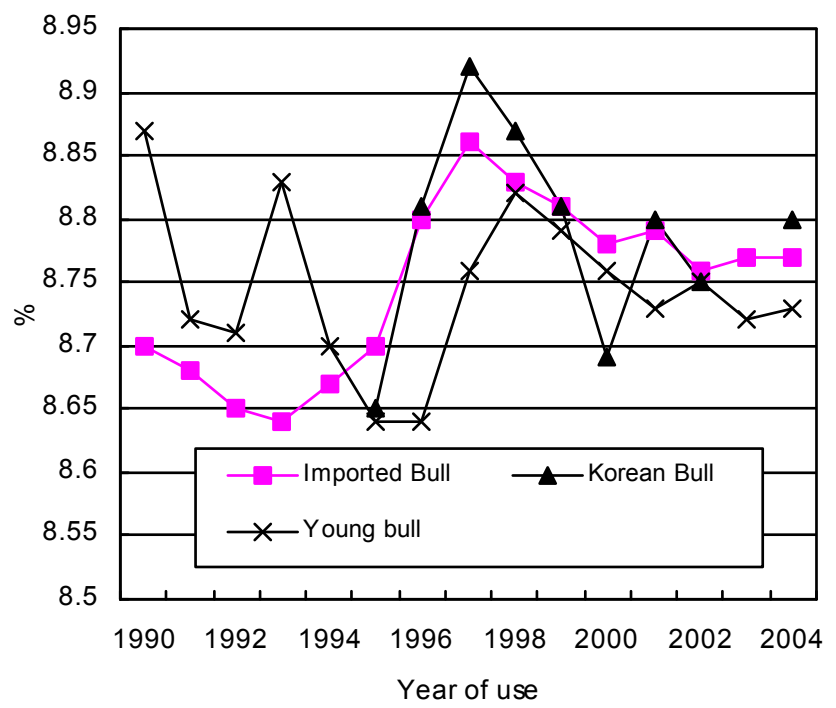

Fig. 4. Least square means of SNF (Solid-Non Fat)\% by year.
와 한국형 보증종모우로 구분하여 능력을 비교해 보면 수 입 보증종모우, 후보종모우, 한국형 보증종모우 순으로 나 타나고 있으나 최근 년도에 가까워질수록 수입 보증종모 우와 국내에서 선발된 종모우간 (한국형 보증종모우와 후 보종모우)의 격차가 점차 줄어드는 경향을 보이고 있을 뿐만 아니라 동일 년도에 사용된 후보종모우의 능력이 한 국형 보증종모우의 능력에 비해 항상 높은 것으로 나타나 우리나라 젖소개량을 위한 종모우 선발이 바람직한 방향 으로 진행되고 있는 것으로 보인다. 유성분 중 유지방은 국내에서 선발된 종모우의 생산능력이 수입 보증종모우에 비해 높게 나타나고 있어 유지방 개량을 목적으로 한다면 우리나라에서 선발된 종모우를 사용하는 것이 수입 보증 종모우를 사용하는 것보다 더 바람직한 것으로 사료된다.

\section{IV. 요 약}

국내에서 동일시기에 사용된 보증종모우(한국형 보증종 모우와 수입 보증종모우 포함)와 후보종모우의 능력을 비 교하기 위하여 1990년부터 2004년 사이에 사용된 종모우 1,128 두의 딸소 148,329 두의 산유능력검정기록을 분석하였 다. 유량의 경우 보증종모우의 생산능력이 후보종모우에 비해 높게 나타나고 있으나 보증종모우를 수입 보증종모 우와 한국형 보증종모우로 구분하여 비교해 보면 동일 년 도에 사용된 후보종모우의 능력이 한국형 보증종모우의 능력에 비해 항상 높은 것으로 나타나 우리나라 젖소개량 을 위한 종모우 선발은 바람직한 방향으로 진행되고 있는 것으로 보인다. 유지방은 국내에서 선발된 종모우의 생산 능력이 수입 보증종모우에 비해 높게 나타나고 있는데 이 는 우리나라에서 종모우 선발을 위한 종합지수식에서 유 지방에 가장 큰 비중을 두고 있기 때문에 나타나는 결과 로 사료된다.

본 연구에서는 각 종모우 딸소들의 평균 생산능력을 이 용하여 종모우의 능력을 비교하였으나 수입 보증종모우의 경우 국내산 종모우에 비해 정액이 고가로 판매되고 있어 농가에서 능력이 우수한 암소에 주로 사용되고 후보종모 우 정액은 무상으로 공급됨에 따라 능력이 낮은 암소에 주로 사용되는 선택적 효과(preferential effect)를 고려할 경 우 국내산 종모우의 능력이 과소평가될 수도 있어 향후 이러한 효과를 고려한 분석이 추가로 이루어져야 할 필요 가 있다.

\section{$\mathrm{V}$. 인 용 문 헌}

1. Abdallah, J. M. and McDaniel, B. T. 2000. Genetic change in milk, fat, days open, and body weight after calving based on three methods of sire selection. J. Dairy Sci. 83:1359.

2. Abdallah, J. M. and McDaniel, B. T. 2002. Proven and young Holstein bulls compared for daughter yields, productive life, somatic cell score, and inbreeding. J. Dairy Sci. 85:665. 
3. Atagi, Y., Jasen, G. B. and Schaeffer., L. R. 1999. Impact of Japanese imported semen evaluations on international bull evaluations. Interbull Bulletin 22, p. 52.

4. Freeman, A. E. 1975. Choosing and sampling young bulls: Theory background, and general problems. J. Dairy Sci. 58:1063.

5. Loyd, B. M. and Hargrove, G. L. 1988. First lactation comparisons between daughters of summarized sires and sampling sires in artificial insemination. J. Dairy Sci. 71 (suppl. 1):235.

6. McCraw, R. L., Butcher, R. and McDaniel, B. T. 1980. Progeny tested sires compared with pedigree selected young sires. J. Dairy Sci. 63:1342.

7. McDaniel, B. T. and Bell, W. E. 1992. Experimental comparison of systems of selecting Holstein bulls. J. Dairy Sci. 75 (Suppl. 1):150.

8. Meinert, T. R., Pearson, R. E. and Hoyt, R. S. 1992.
Estimates of genetic trend in an artificial insemination progeny test program and their association with herd characteristics. J. Dairy Sci. 75:2254.

9. Nizamani, A. H. and Berger, P. J. 1996. Estimates of genetic trend for yield traits of registered Jersey population. J. Dairy Sci. 79:487.

10. Powell, R. L. and Norman, H. D. 1989. Genetic differences among categories of service sires. J. Dairy Sci. 72:1847.

11. Vinson, W. E. and Freeman, A. E. 1972. Selection of Holstein bulls for future use in artificial insemination. J. Dairy Sci. 55:1621.

12. Weigel, K. A. 1996. Impact of second-country data of foreign bulls on international evaluations of dairy bulls. J. Dairy Sci. 79:900.

13. 국립축산과학원. 2008. 젖소유전능력평가보고서.

(접수일자 : 2008. 11. 12. / 수정일자:2009. 4. 16./

채택일자 : 2009. 4. 20.) 